\title{
Overview of the South Carolina State and River Basin Planning Framework
}

\author{
Scott V. Harder ${ }^{1}$, Joseph A. Gellici ${ }^{1}$, Andrew Wachob $^{1}$, and Charles A. Pellett $^{1}$
}

AUTHOR: ${ }^{1}$ South Carolina Department of Natural Resources, P.O. Box 167, Columbia, SC 29202.

\begin{abstract}
Economic development, environmental protection, and public health are critical quality-of-life issues that depend on a reliable supply of water. Increased water demand and climate variability (drought) are two major factors that have the potential to limit future water availability in the state of South Carolina. The development of a comprehensive water-resources management plan for the state is vital for ensuring that an adequate and reliable supply of water will be available to sustain all future uses. The South Carolina Department of Natural Resources (SCDNR) is tasked legislatively with developing water planning and policy initiatives in the state and has initiated a long-term process to update the state water plan, last published in 2004. One of the major recommendations in the 2004 plan was to form River Basin Councils (RBCs) in each of the major river basins in the state for the purpose of water planning. In 2014, SCDNR initiated a multiyear process to develop regional water plans that will serve as the foundation for a new state water plan. A central component of the process was the creation of a Planning Process Advisory Committee (PPAC) for the purpose of developing formal guidelines on the formation of RBCs and the development of river basin plans for the eight designated river basins in the state. The PPAC is composed of a diverse group of stakeholders and includes representation from water utilities, energy utilities, trade organizations, academia, conservation groups, agriculture, and the general public. The work of the PPAC culminated in a report, the South Carolina State Water Planning Framework, which was published in October of 2019. The river basin plans will identify current and future water availability issues and describe a management plan to address these issues to ensure that an adequate and reliable supply of water will be available for future generations. The purpose of this paper is to provide a general overview of the state's river basin planning process.
\end{abstract}

\section{INTRODUCTION}

South Carolina historically has benefited from an abundance of both surface and groundwater resources. The state's water supplies, however, are limited, and adequate supplies of water are vital to the continued growth and economic development of the state and to the well-being of its people and natural environment. South Carolina is susceptible to periodic and multiyear droughts, and as the demand for water increases, the effective management of this precious resource will become increasingly important.

South Carolina's population increased from 3.5 to 5.1 million from 1990 to 2018 and is projected to increase to 5.7 million by 2030 (D. Dickerson, personal communication, January 31, 2019). The state's population growth since 1900, along with population projections for 2020 and 2030, is shown in Figure 1. As the state's population increases, the volume of water used for energy generation, public supplies, and irrigation also may increase.
Although South Carolina usually has an abundance of water, the state has experienced many severe, statewide droughts in its history (Figure 2). Droughts can occur at any time and can last for several months to several years. Recent droughts in 1998-2002, 2006-2009, and 2011-2012 have demonstrated that there are limitations to the state's water supplies. During the drought of 1998-2002, rivers and lakes throughout the state were at historic lows, threatening water-supply intakes and causing saltwater encroachment in coastal areas. Groundwater levels in both shallow and deep aquifers dropped to record lows. The drought of 2006-2009 also was particularly severe, especially in the Savannah River basin; lake levels there dropped faster during that drought than during any other drought on record. Severe, multiyear droughts like those experienced over the past 20 years illustrate the vulnerability of the state's water resources, as well as the wide-ranging impacts droughts can have on agriculture, forestry, power generation, public water supply, tourism, recreation, fisheries, and ecosystems. 


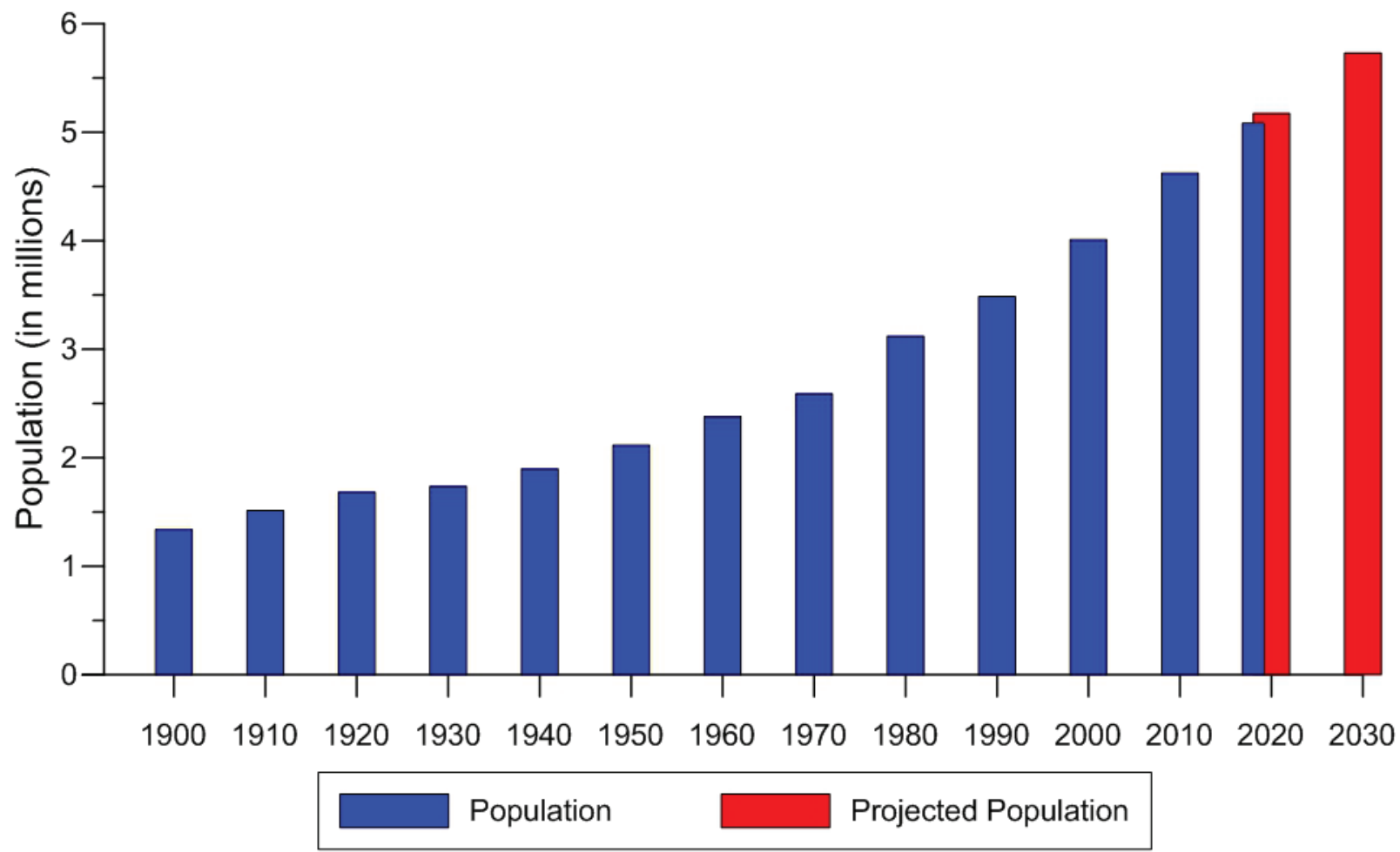

Figure 1. South Carolina population growth from 1900 to 2018 and projections for 2020 and 2030.

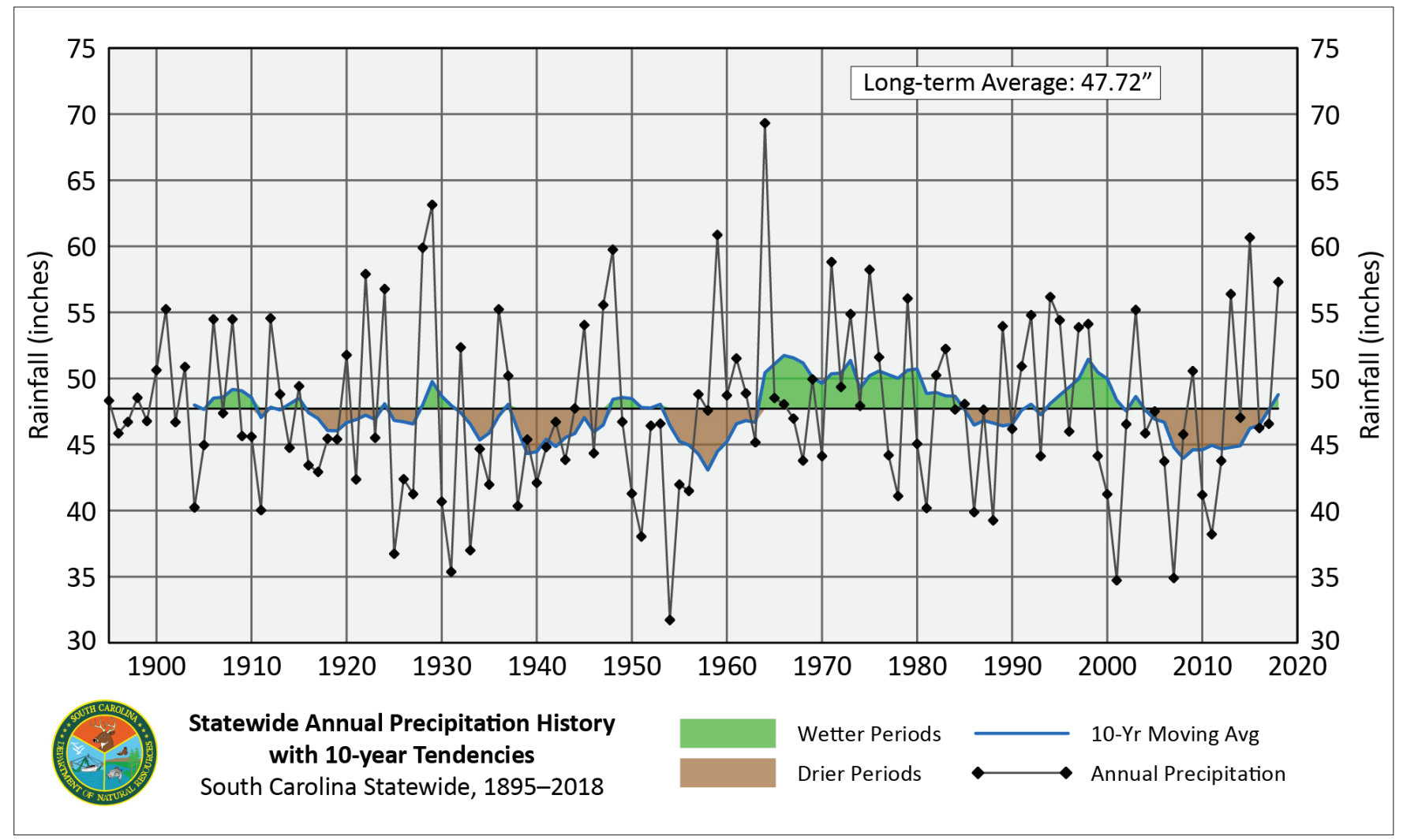

Figure 2. Statewide average annual precipitation for South Carolina, with 10-year averages used to show wetter (green) and drier (orange) periods. While it can be difficult to compare drought impacts across different time periods, this graph shows that South Carolina's most prominent droughts occurred in the 1920s, 1930s, 1950s, 1980s, and 2000s. The state's single driest year was 1954; the statewide average precipitation was 32.96 inches, an approximate 15-inch deficit. (Source: South Carolina State Climatology Office.) 
Increased water demand resulting from population growth will increase competition for water across the state, particularly when the water supply is limited due to drought. The strain that is starting to show on this limited resource has highlighted the importance of developing long-term, comprehensive, statewide water-resource management plans that will allow for the continued growth of the state's population and economy while protecting the state's water resources for generations to come. The purpose of this article is to describe South Carolina's current state and river basin planning process that is being implemented to address the long-term water management of the state's water resources.

\section{BACKGROUND AND RELATED WORK}

The South Carolina Department of Natural Resources (SCDNR) is legislatively mandated through the South Carolina Water Resources Planning and Coordination Act ( $\$ 49-3-10$, et seq., Code of Laws of South Carolina, 1976, as amended) to formulate and establish a comprehensive water resources policy for the state, which is presented in a document known as a water plan. A state water plan presents a water vision for the state; articulates the state's waterresource policies and goals; and can be used to develop or modify legislation, regulations, and programs that help the state achieve those goals.

The first edition of the South Carolina Water Plan was published by SCDNR in 1998 (Cherry and Badr, 1998). The plan was updated in 2004 (Badr et al., 2004) and offered 81 policy recommendations and guidelines for the efficient, economical, and environmentally responsible management of the state's water resources. One recommendation was to establish an advisory committee for each of the state's four major river basins - the Ashepoo-Combahee-Edisto (ACE), Pee Dee, Santee, and Savannah basins - that would work to optimize water use throughout each basin. Recognizing the multitude of users and the complexity of water issues that occur in a basin, the 2004 plan recommended that each committee be composed of representatives from federal, state, and local agencies and stakeholders who would work together to develop basin-wide water management plans.

In 2014, SCDNR initiated a long-term process for developing the basin-wide water management plans. These basin-management plans, now formally designated as river basin plans, will form the foundation of a new state water plan. Although the 2004 South Carolina Water Plan recommended developing water plans for the state's four major basins, SCDNR and the South Carolina Department of Health and Environmental Control (SCDHEC) subsequently decided to subdivide two of the larger basins. The Santee basin was divided into the Saluda, Broad, Catawba, and Santee basins, and the ACE basin was divided into the Edisto and Salkehatchie basins, with the Ashley-Cooper basin included in the Santee basin. Therefore, river basin plans will be developed for each of the following eight river basins: Broad, Catawba, Edisto, Pee Dee, Salkehatchie, Saluda, Santee, and Savannah (Figure 3). The boundaries of these eight river basins were selected to match the basin delineations used by SCDHEC for its water-quality assessments and for the permitting of interbasin water transfers.

Although the 2004 water plan recommended the formation of water-planning committees for regional planning purposes, it did not offer sufficient guidance regarding the membership and duties of such councils, nor did it detail the contents of a river basin plan or describe how those plans would be developed. The legislative mandate that calls for SCDNR to formulate and establish a comprehensive water-resources policy for the state also authorizes SCDNR to appoint interdepartmental and public advisory boards as necessary to advise and assist in developing policy recommendations to the governor and the general assembly. To that end, SCDNR established the State Water Planning Process Advisory Committee (PPAC) in 2018 to assist with establishing a framework for developing river basin plans in the state. The PPAC is a diverse group of 19 water-resource experts representing water suppliers, agriculture, trade, conservation organizations, state agencies, and academia.

The PPAC's work is guided by its vision: "Reflecting our values of water as a shared resource with a shared responsibility, we will work together to develop and maintain an actionable State Water Plan balancing economic, environmental and social needs of South Carolina for generations to come." It was tasked with developing a set of guidelines in appropriate detail so river basin plans can be successfully prepared and implemented. These guidelines were documented in a report, the South" Carolina State Water Planning Framework (Planning Framework), published in October of 2019 (SCDNR, 2019). Specific topics addressed in the Planning Framework include:

- River Basin Council (RBC) membership and appointment process

- Roles and responsibilities of RBCs

- Roles and responsibilities of state and federal agencies

- Methods for identifying and addressing water availability issues

- Contents of river basin plans

- Public and stakeholder participation

The long-term process to develop river basin plans and a new state water plan can be divided into three components: (1) the development of surface and groundwater resource assessments and future water demand projections, (2) the formation of River Basin Councils (RBCs) tasked to develop 


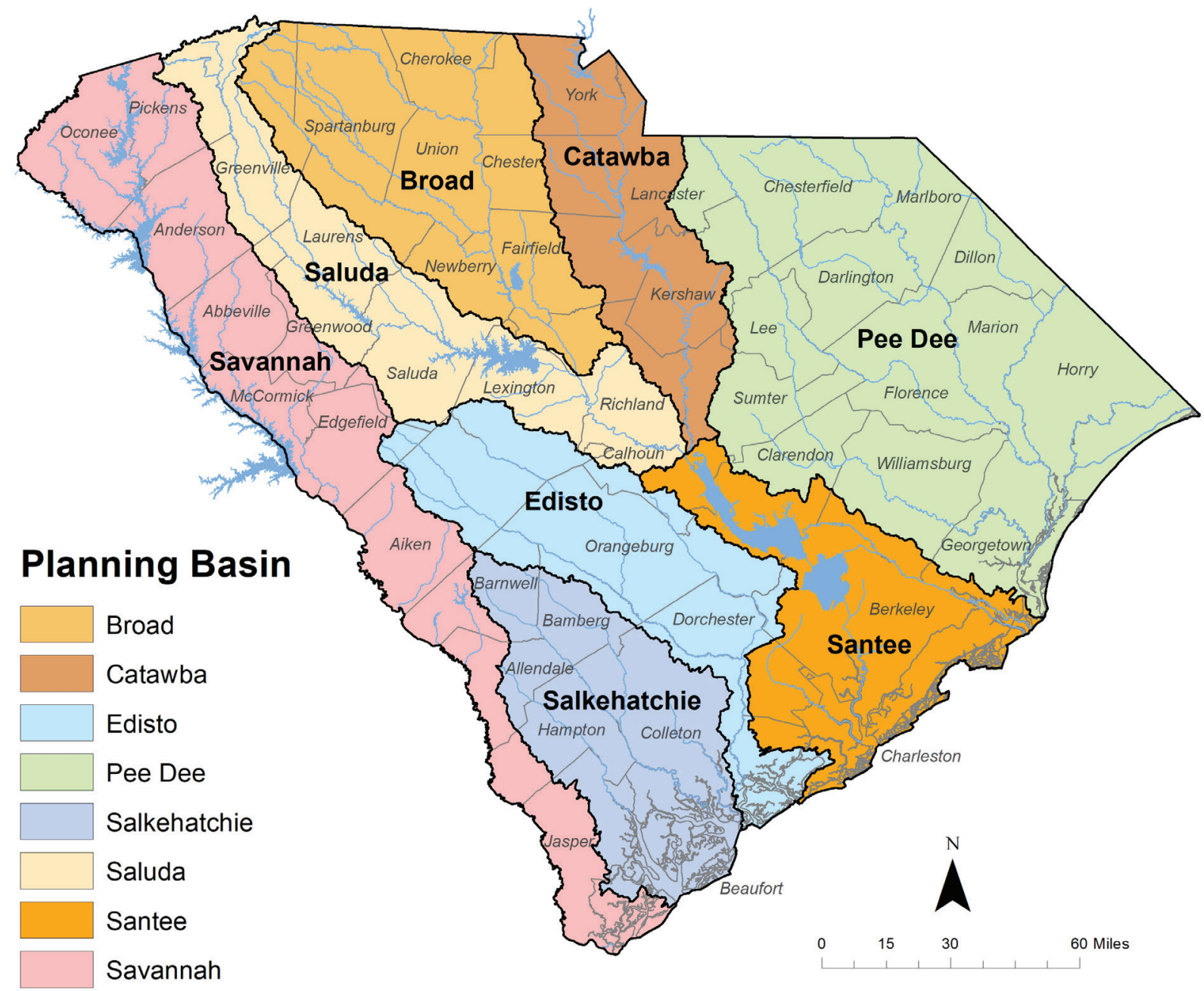

Figure 3. Map showing South Carolina's eight river basin planning areas.

river basin plans for each basin as described in the Planning Framework, and (3) the development of a new state water plan under the guidance of the Planning Framework and based on information and recommendations produced in the river basin plans. Each one of these components is described in more detail below.

\section{DEVELOPMENT OF RESOURCE ASSESSMENTS AND WATER DEMAND PROJECTIONS}

The evaluation of water availability in each river basin and any resulting water-management strategies or recommendations made by an RBC must rely on sound science and reliable decision-making tools. To address those needs, SCDNR, in cooperation with SCDHEC, completed a set of hydrologic models for the state's surface and groundwater resources. In addition, SCDNR is in the process of completing water-demand projections for each basin that can be incorporated into the hydrologic models. The models and water-demand projections are intended to provide information on current and future water availability and will help identify any existing or future water shortages or issues. These assessments also can be used to evaluate alternative water-management strategies that can address or mitigate future water shortages or stresses on the state's water resources.

\section{SURFACE-WATER MODELS}

In August 2014, SCDNR contracted CDM Smith, Inc., to complete surface-water models for the eight planning basins in the state (Figure 3) using the Simplified Water Allocation Model (SWAM). The SWAM model provides a consistent technical platform in each river basin with which to evaluate water availability. Eight SWAM models, one for each basin, were completed in 2017 and serve as the primary models for assessing surface-water availability.

SWAM is an Excel-based, water-allocation model that computes physically and legally available water at userdefined nodes in a networked river system. The model incorporates water withdrawals and discharges and can 
simulate reservoir operations of varying complexity. SWAM was developed to provide efficient planning-level analyses of water supply and river basins, while maintaining a high level of accessibility to a wide range of end users. More information about the SWAM model and its functionality can be found in the South Carolina Surface Water Quantity Models Modeling Plan report (CDM Smith, 2014).

\section{COASTAL PLAIN GROUNDWATER MODEL}

In February 2016, SCDNR contracted the US Geological Survey in Columbia, South Carolina, to update the South Carolina Coastal Plain Groundwater Flow Model, which had initially been completed in 2010 (Campbell and Coes, 2010). The model is being updated using MODFLOW-NWT (Niswonger et al., 2011) and is scheduled for completion in the spring of 2020. Updates will include modifying the surficial aquifer model layer; adding recent groundwaterrelated data such as water-use data, hydraulic properties of aquifers obtained from pumping tests, groundwater levels, and hydrogeologic information from water wells, core holes, and well-cluster sites; reducing the model grid from $2 \times 2$ miles to $2,000 \times 2,000$ feet; incorporating a more detailed representation of the fall line area; incorporating modeled groundwater-recharge rates; recalibrating the model; and applying the model to a series of seven scenarios.

The updated groundwater flow model will be used to simulate the effects of future water use development and provide insights into various potential management strategies. The South Carolina Coastal Plain Groundwater Flow Model will serve as the primary model during the regional water planning process for assessing groundwater availability.

\section{WATER-DEMAND PROJECTIONS}

An assessment of future water availability requires an estimate of future water demand in each planning basin. To that end, SCDNR, in a joint project with the US Army Corps of Engineers and Clemson University's South Carolina Water Resources Center, developed population and water-demand projection methodologies. The projection methodologies are documented in a report, Projection Methods for Off-stream Water Demand in South Carolina, published in October 2019 (Pellett, 2019). The methodologies will be applied in each basin to estimate future water demand over a 50-year planning horizon for thermoelectric power, public supply, industry, agricultural irrigation, domestic supply, and golf course irrigation.

Two sets of projections will be developed. The first set of projections will represent a future demand based on normal climate conditions and average economic growth; the second set will represent a high future water-demand scenario based on drought-year conditions and above-average economic growth. The projection will be completed in 5-year intervals for the first 20 years and in 10-year intervals for the following 30 years. This information will be used in the surface and groundwater models to assess future water availability.

\section{RIVER BASIN PLANNING}

A river basin plan is generally a collection of watermanagement strategies designed to ensure that the surface water and groundwater resources of a river basin will be available for all uses, both instream and offstream, for years to come, even under drought conditions. A river basin plan generally addresses four questions:

1. What is the basin's current available water supply and demand?

2. What are the current permitted and registered water uses within the basin?

3. What will be the water demand in the basin throughout the Planning Horizon and will the available water supply be adequate to meet that demand?

4. What water management strategies will be employed in the basin to ensure the available supply meets or exceeds the projected demand throughout the Planning Horizon?

The first three questions are essentially technical in nature and can be addressed using the surface water- and groundwater-resource assessments in conjunction with the water-demand projections described above. Answering the fourth question is at the heart of the water-planning process and greatly benefits from cooperation and consensus among stakeholders throughout the basin. A successful and equitable river basin plan addresses the effects that all water users have on one another and on the resource.

For each river basin, development of the river basin plan will be the responsibility of an RBC created specifically to accomplish this task. As described in the Planning Framework, each RBC will consist of no more than 25 members, appointed by SCDNR, who have a water-resources background or a vested interest in the water resources of the basin. A river basin plan will be developed for each of the state's eight major river basins and are intended to assess water availability and use throughout a basin, identify and evaluate current and/or future water-resource shortages or other concerns, and recommend strategies for resolving those concerns. The river basin plans also may include legislative or policy recommendations for the state to consider, but such recommendations are subject to SCDNR approval before their inclusion in the state water plan.

To successfully complete the roles and responsibilities prescribed for the RBCs in the development of river basin plans, those appointed councils will require significant 


\section{Overview of the South Carolina State and River Basin Planning Framework}

support from qualified personnel capable of performing the many tasks necessary to run productive meetings and keep the process of preparing a successful, actionable plan on track. Though SCDNR and SCDHEC will work closely with RBCs in the planning process, the support necessary for RBCs to fulfill their responsibilities will come primarily from private contractors who specialize in the various aspects of the water planning process. Five general types of functions needed for the planning process are administrative, facilitative, technical, public outreach, and report preparation.

\section{NEW STATE WATER PLAN}

Upon completion of the eight river basin plans and their approval by SCDNR, staff at SCDNR will write the state water plan using the guidelines outlined in the Planning Framework. The state water plan will be a compilation of key information from the river basin plans that is presented for the state as a whole and in a manner that illustrates differences among the river basins in terms of water use, availability, demand, and water-management strategies. The state water plan also will serve as a policy document that summarizes and prioritizes water policy and program recommendations that were made in the river basin plans. Recommendations on improving the water planning process, enhancing stakeholder and public participation, implementing and financing water plans, and introducing innovative water-management practices also will be described.

\section{STATE AND RIVER BASIN PLANNING PROCESS IMPLEMENTATION}

The exact timeline to complete all eight river basin plans and the new state water plan will be heavily dependent on available funding, but it is currently planned as a 5-year process. The implementation of the river basin planning process and the formation of the first RBC as described in the Planning Framework began in the pilot basin (Edisto River basin) in the fall of 2019. The initiation of planning activities in the other basins will be staggered over the next several years, depending on available funding. The development of a final river basin plan for a given basin is expected to be a 2-year process, and it is anticipated that all eight plans will be completed by 2023 . Once the eight river basin plans are finalized, a new state water plan will be developed by 2024 . However, the schedule for the completion of the river basin plans and the state water plan is subject to change based on available funding.

SCDNR will serve as the primary oversight agency during the state and river basin planning process. Specific SCDNR tasks will include soliciting contractors to support plan development; ensuring work is completed by contractors in a timely manner according to the defined scope of work; overseeing the planning process to ensure consistency with guidelines established in the Planning Framework; communicating with state and federal agencies, stakeholders, and the general public on planning activities; and serving in a general advisory role on the management of the state's water resources. The Planning Framework also outlines formal guidelines for evaluating the progress made on developing a given river basin plan and for keeping RBCs on schedule. Milestones and metrics of success regarding plan development will be established for the purpose of keeping RBCs on schedule.

Effective public participation during all stages of the river basin planning process will be critical for successful water planning. To that end, RBC activities and the planning process are designed so that transparency, timeliness, accuracy of information exchange, and twoway communication between RBCs and the public are key priorities. RBCs will work in cooperation with contractors including public outreach coordinators to develop protocols and mechanisms that adhere to state open meeting laws and additional guidelines provided in the Planning Framework.

\section{REFERENCES}

Badr AW, Wachob A, Gellici JA. 2004. South Carolina Water Plan, 2nd ed. Columbia (SC): South Carolina Department of Natural Resources. http://hydrology.dnr.sc.gov/pdfs/ water-plan/SCWaterPlan2.pdf.

Campbell BG, Coes AL, editors. 2010. Groundwater availability in the Atlantic Coastal Plain of North and South Carolina (Professional Paper 1773). Reston (VA): US Geological Survey.

Cherry RN, Badr AW. 1998. South Carolina water plan. Columbia (SC): South Carolina Department of Natural Resources. http://hydrology.dnr.sc.gov/pdfs/water-plan/ SCDNR_Water_Plan_1998.pdf.

CDM Smith, Inc. 2014. South Carolina surface water quantity models modeling plan. Columbia (SC): South Carolina Department of Natural Resources. http:// hydrology.dnr.sc.gov/pdfs/swm/TechnicalReports/ ScSwqmModelingPlan.pdf.

Niswonger RG, Panday S, Ibaraki M. 2011. MODFLOWNWT, A Newton formulation for MODFLOW-2005. U.S. Geological Survey Techniques and Methods 6-A37. Reston (VA): USGS.

Pellett A. 2019. Projection methods for off-stream water demand in South Carolina. Columbia (SC): South Carolina Department of Natural Resources. http:// hydrology.dnr.sc.gov/water-demand.html.

SCDNR. 2019. South Carolina State water planning framework. Columbia (SC): South Carolina Department of Natural Resources. http://hydrology.dnr.sc.gov/stateand-river-basin-planning.html. 